'The times they are a-changin'’: Party campaign strategies in the 2018 Italian election $^{1}$

Vincenzo Emanuele, Department of Political Science, LUISS - Guido Carli, Rome, Italy

Nicola Maggini, Department of Legal Sciences, University of Florence, Italy

Aldo Paparo, Department of Political Science, LUISS - Guido Carli, Rome, Italy

Corresponding author: Aldo Paparo, Department of Political Science, LUISS - Guido Carli, Rome, Italy, Viale Romania 32, 00197 - Rome, Italy. E-mail: apaparo@luiss.it.

${ }^{1}$ Accepted manuscript for publication: post-print version. The Version of Record of this manuscript has been published and is available in West European Politics, 30 September 2019, http://www.tandfonline.com/doi/full/10.1080/01402382.2019.1655966 


\title{
'The times they are a-changin': Party campaign strategies in the 2018 Italian election
}

\begin{abstract}
The 2018 Italian election featured striking results, with both a historic success for the two challenger parties (League and M5S) and massive defeats for the two mainstream parties (PD and FI). In this article, we analyse party campaign strategies, and their consistency with the opportunity structures provided by the configuration of Italian public opinion. Relying on issue yield theory, we collected original survey data for both issue support and priority among Italian voters, and party emphases on issues in the electoral campaign - through Twitter data. Our findings indicate a generalised ideological inconsistency of the constituencies of main parties, while campaign strategies appear much more ideologically consistent. Moreover, we find that parties focussed mostly on conflict-mobilisation strategies, rather than on problem-solving. Finally, we show that, in general, parties acted strategically, by aligning their campaign to the available opportunities, although with relevant variations across parties.
\end{abstract}

Keywords: 2018 Italian general election; issue yield theory; party competition; valence politics; Twitter data.

The 2018 Italian election results were a second electoral turmoil, after the earthquake of 2013 (Chiaramonte and De Sio 2014). The two main challenger parties - the Five Star Movement (M5S) and the League - combined received the majority of the votes. This represents an unprecedented event not only with reference to the Italian case, but in comparative Western European perspective. On the contrary, both main mainstream parties scored their historic lowest results. Specifically, the Democratic Party (PD) fell to $18.7 \%$, with Go Italy (FI) to $14.0 \%$.

Looking at the results more broadly (see Figure A1 in Appendix B), the centre-right coalition - League, FI, Brothers of Italy (FDI) and a minor centrist ally - won a plurality of the votes (37\%), falling short of a majority in both Parliament branches. The League quadrupled its 2013 result, reaching $17.4 \%$ and becoming the first time the leading party in the centre-right. The M5S was the most-voted single list with $32.7 \%$. Thus, it is the first successful debutant in post-WW2 Western Europe to increase its votes in the following general election - it actually gained seven percentage 
points. The centre-left became the third pole, with $22.9 \%$ of the votes, which constitutes the worst electoral result of the left bloc since 1948. It was formed by the PD and three minor centre-left parties, while its left-wing splinter - Free and Equal (LEU) - ran separately.

In light of these electoral results, showing remarkable electoral change, it appears particularly noteworthy investigating the campaign strategies pursued by the different parties to maximise their electoral returns. In this regard, two recent developments are crucial: the rebranding of the League by the new leader (Matteo Salvini), from an ethno-regionalist party of the North (Tronconi 2009) to a nationwide radical right-wing party (Tarchi 2018); and the evolution of M5S under the new leadership of Luigi Di Maio, who tried to establish the party as a credible governing alternative.

In this article we study party strategies during the 2018 electoral campaign, through the lenses of the issue yield theory (De Sio and Weber 2014). In particular, we will address three research questions, which constitute the overarching analytic framework of this special issue (De Sio and Lachat in this issue). First, we will assess the ideological consistency of party constituencies and party strategies (RQ1). Second, we investigate the presence of conflict-mobilisation strategies, based on the emphasis on positional, divisive issues, or strategies based on problem-solving, focussing on the ability of the party to achieve valence, shared goals (RQ2). Finally, we will provide a general test of the fit of the issue yield theory in the Italian case: namely, whether parties behaved strategically, by emphasising those specific issues on which they had a competitive advantage, or simply mirrored the issue priorities of the electorate (RQ3).

The paper is structured as follows. First, we present the Italian case which is the focus of our investigation. Then we detail the theoretical framework, the research questions and propositions. The third section discusses our methodological choices. Then, the fourth section is devoted to the investigation of the issue opportunities for Italian parties. The next section analyses party campaign strategies. Finally, we empirically assess the strategicness of Italian parties in their electoral campaigns. A concluding section follows. 


\section{The Italian case}

In order to investigate whether party campaign strategies can be interpreted through the lenses of issue yield theory (which will be discussed more in depth in the next section), the Italian case appears particularly promising for a number of reasons, with specific regards to its recent developments. In particular, we refer to the extraordinary fluidity of the Italian electoral environment, characterised in recent times by high levels of electoral volatility (Chiaramonte et al. 2018); the rise of successful new parties, explicitly rejecting the traditional left-right dimension - to begin with the M5S (Bordignon and Ceccarini 2013; Maggini 2014); and the development of problem-solving strategies by mainstream parties, recently confronted by conflict-mobilisation adopted by challenger parties.

For a long time after WW2, the Italian party system was one of the most stable in Western Europe, both in terms of party supply and vote choice (Bartolini and Mair 1990). This stability was rooted in the strength of the cleavage structure, made up of the overlap between the class cleavage and the religious cleavage (Dogan 1967), and the consequent strength of ties between social groups and their parties. After the collapse of the party system in the early ' 90 s, a new bipolar pattern of competition emerged in which the left-right dimension replaced group loyalty as the structuring element of the Italian political space (Biorcio 2010), granting a new period of electoral stability, which lasted until the earthquake election of 2013 (Chiaramonte and De Sio 2014). Thus, throughout the whole 1948-2013 period, the political conflict was mostly organised on a single dimension of conflict (Sani and Sartori 1978; Biorcio 2010), which was able to reproduce stability by absorbing multiple cultural and socio-economic divides, as well as new challenges emerging.

Since 2013, the increasing electoral volatility and the emergence of new successful parties explicitly rejecting the traditional left-right dimension (M5S, Civic Choice) clearly indicate the collapse of the traditional stability anchored on the one-dimensionality of the political space. In this de-structured context, new opportunities open up to strategic political entrepreneurs able to exploit the (perhaps ideologically contradictory) issue opportunities they are offered, given that now many 
voters are available on the electoral market, as they are much less constrained by ideological considerations. This is exemplified by the electoral success of the two main challenger Italian parties (M5S and League), although the two present a fundamental difference. The League is clearly a niche party with an undisputedly radical right-wing party connotation (Mudde 2007), while the M5S presents peculiar features which make it more similar to a catch-all party (Kirchheimer 1966). Since its birth, the M5S has refused the left-right dimension, has appealed to the whole Italian citizens (rather than to specific social groups), and has never been allied in any form to any party. Based on these elements, the M5S could be almost conceived as a genuine catch-all party. Moreover, as anticipated above, compared to Beppe Grillo's former leadership, Di Maio has been much more moderate and inclusive.

In many European countries this process of citizen de-ideologization was first exploited, from the 1980 s on, by mainstream parties wishing to deploy catch-all appeals relying on their claimed superior a-ideological problem-solving competence, as previously mentioned. With specific reference to the Italian context, for instance, Matteo Renzi's PD won the 2014 European Elections clearly relying on a problem-solving strategy based on valence issues (De Sio 2014). On the contrary, recent years have seen the rise of niche, challenger parties, such as the League, focusing on conflictual issues, such as immigration (Mudde 2011), whose demarcationist option is increasingly shared by citizens across ideological boundaries, especially after the economic and refugee crisis.

\section{Theoretical framework and propositions}

This article adopts a theoretical framework based on the issue yield theory (De Sio and Weber 2014; De Sio et al. 2016; De Sio et al. 2018), which considers contemporary party competition best understood in terms of issue competition (Carmines and Stimson 1980; Green-Pedersen 2007). The basic idea behind issue yield is that each issue provides a unique combination of opportunities and risks, which can be summarised by looking at voter preferences within the party and in the whole electorate, and party credibility. In particular, opportunities will be higher when the party 
constituency agrees on the issue, along with the overall electorate, and the party is deemed credible by the electorate in dealing with it. On the contrary, risks will be higher when on an issue the party constituency is divided, the overall electorate is divided as well, and the party is not credible.

According to this conceptualisation, during the electoral campaign, parties are theoretically expected to emphasise those issues offering them the best opportunities, while silencing those presenting high risks, in order to maximise their electoral returns. The theory is particularly profitable as it is expressly developed to cope with both valence and positional issues (Stokes 1963) - see the next section for details on how exactly this is possible - and in light of the recent demise in the role of traditional ideological lines of conflict (Dalton 1984; Franklin 1992).

To recall, positional issues are those on which two rival goals are desired by parts of the electorate (i.e. welfare vs. low taxes), while valence issues relate to goals shared by the whole electorate (i.e. fight against corruption, national security). The issue yield theory argues that on positional issues, parties take different positions, and voters evaluate them on the positions, and their credibility; while on valence issues parties show no differences in the positions and are judged solely by their credibility in realising the related shared goals.

Based on the issue yield theory and the considerations on the Italian case presented in the previous section, our contribution will address three specific propositions, specifically developed for the Italian case, about empirical expectations related to the three research questions anticipated in the introduction that we investigate in this paper - which constitute the overarching analytic framework of this special issue (De Sio and Lachat in this issue).

First, we will assess the ideological consistency of party constituencies and party strategies (RQ1). The degree of ideological consistency of party constituencies is clearly relevant in shaping the kind of strategies parties might actually pursue when campaigning on issues. Indeed, when the electorate is showing a classic, unidimensional left-right polarisation, party strategies will be necessarily less flexible than when the electorate is a-ideological. In the latter case, it is actually possible for parties to create unprecedented issue packages, by cherry-picking goals from both the 
traditional $20^{\text {th }}$-century left and right. Thus, on this first research question, we formulate a first proposition as follows.

Proposition 1: We expect ideological inconsistency both in the party electorates and party strategies.

Second, we will look at the issue strategies pursued by Italian parties. Do parties campaign more on positional or on valence issues? Namely, we investigate the presence of conflict-mobilisation strategies, based on the emphasis on positional, divisive issues, or strategies based on problemsolving, focussing on the ability of the party to achieve valence, shared goals (RQ2). From a theoretical viewpoint, the literature suggests mainstream parties to campaign mostly on valence issues, following a problem-solving strategy (Clarke et al. 2009). Conversely, niche parties are expected to campaign mostly on positional issues, following a conflict-mobilisation strategy (Meguid 2005; Van de Wardt et al. 2014). Consequently, our second proposition, is as follows.

Proposition 2: We expect mainstream parties (e.g. PD and FI) to have their best opportunities on valence goals and thus mostly campaign on problem-solving strategies, and the niche and challenger parties (e.g. the League) to have their best opportunities on positional goals, and thus mostly campaign on conflict-mobilisation. ${ }^{1}$

Finally, we will provide a general test of the fit of the issue yield theory in the Italian case (RQ3): namely, whether parties behaved strategically, by emphasising those specific issues on which they had a competitive advantage, or simply mirrored the issue priorities of the electorate (Ansolabehere and Iyengar 1994). It is important to underline that, according to issue yield theory, parties should emphasize their most profitable issues, regardless of the type of issue. This means that strategic emphasis can be put, by all kind of parties (mainstream or challenger, niche or catch-all), on all kinds of issues (ideologically consistent among each other or not, valence or positional), as long as this is consistent with their opportunities. Thus, we can say that issue yield theory is agnostic in terms of which issues should be emphasized by the different parties, although it is undoubted that specific contextual features, by relaxing or restricting constraints, might make it more or less possible for parties to fully adapt their strategies to actually available opportunities. 
As a result, this is our third proposition.

Proposition 3: We expect Italian parties to emphasize in their electoral campaigns those issues providing them with the best issue-yield opportunities, instead of simply reproducing in their issue emphasis the overall issue priorities of the general public.

\section{Data and methods}

To understand the interplay between party strategies and electoral incentives, we rely on an approach that combines two original data sources: a pre-campaign survey on a representative sample of the Italian voting-age population, and all the messages posted on Twitter by the main parties and their leaders during the electoral campaign. The voter survey aims at capturing issue opportunities for parties; coding of tweets allows measuring party strategy in terms of issue emphasis. Social media, and Twitter in particular, offer a useful tool to capture party strategic communication. They represent the most widely accessible form of party communication, as through Twitter we can expect parties to be able to employ strategies much more than on their electoral platform, which could represent a possible alternative via Manifesto data (Graham et al. 2013).

\section{Voter Survey}

A Computer-assisted web interviewing (CAWI) survey was fielded before the March 4 election (6-12 February) among a quota sample of 1,000 Italian citizens over the age of 18. The sample was representative of the voting-age population in Italy based on gender, age group, geographic area, and education. According to AAPOR standards for non-probability internet panels, the participation rate (i.e., the number of respondents who have provided a usable response divided by the total number of initial personal invitations requesting participation) was $49.04 \%$. Respondents were asked items regarding their policy preferences and priorities, and perceived credibility of political parties to achieve the policy goals. Overall, 12 valence and 22 positional issues were measured. On positional issues, respondents had to choose between two opposing goals, placing 
themselves on a six-point scale. ${ }^{2}$ For issues identified as valence, support for a single goal was assumed for all respondents (Stokes 1963). For both valence and positional goals, respondents were asked about the priority they attached to the goal, and about the parties they considered credible in achieving it. ${ }^{3}$ The issue selection process was designed to address all topics debated during the campaign and to cover different policy domains.

\section{Twitter campaign analysis}

In the two months preceding the election day (from January 7 to March 4), we have collected, for the main parties competing in the election, all tweets retrieved from their official Twitter accounts and from the account of their leader. We identified the official Twitter accounts for seven parties PD, M5S, FI, League, FDI, LEU, Più Europa (+EUR) - and their leaders - Matteo Renzi, Luigi Di Maio, Silvio Berlusconi, Matteo Salvini, Giorgia Meloni, Pietro Grasso, Emma Bonino. After deletion of replies and retweets, 17,667 tweets remained for inspection. During the coding procedure, tweets not related to policy issues were removed (92.8\%), while each of the 1,292 policy tweets was manually assigned by human coders to one of the 34 issues included in the survey. All tweets were coded independently by two coders. Each coder read each tweet and separately decided which of the 34 issues measured in the voter survey it belonged, and coded it accordingly. The occurrence of tweets dedicated to issues not included in the original 34-items list was negligible (19 out of a total of 17,667 tweets). This represents a confirmation of the overall validity of our ex ante issue selection. These 19 tweets have been excluded from the analysis. The inter-coder reliability measured by the Cohen's kappa statistic resulted $0.90 .^{4}$ Thus, considered the high level of intercoder reliability, the classification of the coder assigning the highest number of tweets to issue content was preferred. We then merged the survey dataset and the Twitter content analysis dataset to compare and contrast parties' opportunities and their campaign strategies. 


\section{Method}

In order to address our first two propositions, we provide descriptive statistics of public opinion and Twitter data. Moreover, we use regression analysis to address the third proposition, namely that Twitter issue emphasis (IE) can be better predicted by issue yield rather than by systemic issue salience (SS). The unit of analysis is parties*issues (7 parties*34 issues, for a sample size of 238). As discussed above, according to issue yield theory, any goal defined over a specific issue offers to a party a combination of electoral risks and opportunities that is defined by two properties: support for the goal (overall and within the party), and voters' credibility of that party on that goal. Following the refined operationalisation presented by De Sio and Weber (in this issue), it is possible to compute a summary index (issue yield, IY) which expresses, for each party on each policy goal, how good the combination of risks (of losing existing voters) and opportunities (for gaining new votes) is. This index is expressly designed to be applied to both positional and valence issues. However, for valence issues this entails that IY is calculated only on the basis of the party's credibility in achieving the goal, as support is assumed unanimous (see Appendix A and De Sio and Weber in this issue).

SS represents the aggregate priority scores of voters given to an issue (Steenbergen and Scott 2004; Kaplan et al. 2006; Wagner 2012) and it is calculated as the percentage of all respondents that reports the issue as 'high' priority, with respondents reporting 'medium' priority being counted as half.

IE, allowing to describe party strategy, is measured as the share of tweets related to an issue. This means that the dependent variable represents a proportion; consequently, it is constrained between 0 and 1 . Following previous research on issue yield paying specific attention to this methodological challenge (De Sio et al. 2018: 15), we employ Tobit regressions for our empirical tests. $^{5}$ 


\section{The demand side: issue opportunity configurations for parties}

We begin our empirical inquiry by looking at Italian public opinion. In particular, we look at the opportunity configurations available for Italian parties emerging from survey data, addressing, specifically, the demand side of propositions 1 and 2. In order to investigate the former, we report Figure 1, which shows, for the main parties, where their electorates stand on the various positional issues, along with their relative salience (represented by the size of the indicator). In a nutshell, the electorates of main Italian parties appear quite ideologically inconsistent.

Looking into detail, M5S voters are leftist on the economy but quite close to right-wing voters on Europe and immigration. In general, the average position of the M5S electorate is the closest to the median voter. League voters are unsurprisingly the most against immigrants, Europe, and globalisation. However, it is worth noting that they are quite 'leftist' in terms of economic policy. Only on fiscal progressivity, a tiny majority $(50.1 \%)$ of League voters wants the right-wing choice (Flat tax), despite this being one of the signature proposals of the party platform (and being hardly campaigned on, see below).

Turning to mainstream parties, FI voters are even more left-wing on the economy than League ones, quite surprising considering that FI, since its birth, has pushed for the 'pro-market revolution'. However, there are also exceptions to this pattern, namely on globalisation, on which FI voters appear more consistent with the right-wing expected position - and the platform of their own party. Conversely, PD voters are the most ideologically consistent. They are on the left-wing side on all economic issues. However, they fall on the right-wing side on globalisation and number of refugees. They are the most pro-European, so much that the PD electorate is very distant from all other electorates - and not just the League's, whose majority is on the other side of the two EU-related issues. This is actually a more general trait - PD voters being far from all other major electorates.

The issue of globalisation is particularly interesting as it is the only one on which voters of mainstream parties are on the same side and opposed to voters of challenger parties. On the other hand, in this de-ideologized context, our data show that Italian voters, regardless of their party 
preference, agree on many policy divisive goals, starting with social-democratic economic goals. Data show that there is basically no difference among the four electorates on desiring a minimum hourly wage and a reduction of income differences.

A similar agreement can also be found on civil rights: all four electorates are pro-choice, although more relevant differences appear. But the clear difference emerges as salience is concerned: all four electorates care more for the economy than civil rights (average goal salience is reported as size of the party marker). Conversely, there is no consensus on cultural issues. Conservative goals prevail on such dimension, but with more divisions. The only issue on which all four electorates favour a right-wing goal is on reducing the number of refugees. However, its level of support is much higher than on consensual left-wing economic goals. Here it goes from $90 \%$ or more for FI and the League, to $56 \%$ for the PD. There is also much more variation in terms of salience: for centre-right voters (and League voters in particular), anti-immigrant goals are crucial; while for M5S and PD voters, economic goals are more important.

[Figure 1 here]

Moreover, the pronounced ideological inconsistency of M5S voters is further reinforced by looking at another piece of evidence. Table 1 reports for each of the four major Italian parties, their most-profitable policy goals in terms of IY, along with their cross-party ranking on that issue. The latter indicates the ranking of the IY score for that party on that goal compared to the IY scores for other parties on the same goal. ${ }^{6}$ Shared, valence goals are in italics. The M5S displays, among its best issue opportunities, all valence issues except one. This is in line with the internal division of its electorate on most positional issues.

This valence-dominated profile for the M5S leads us to properly address Proposition 2 with specific reference to the demand side, which refers to the prevalence of valence vs. positional opportunities (and strategies, discussed in the next section). The first striking element is that, among 
the four major parties, mixed results emerge. On one side, the M5S and, to a lesser extent, FI are characterised by the already mentioned prevalently valence profile. On the other side, the League and the PD face their best campaign opportunities on positional issues. These findings partially contradict Proposition 2. FI and League confirm our expectations, but the PD does not. So, the League and the PD show their best issue opportunities on cultural conflicts. The League is the culturally conservative party, in particular on immigration, which makes it very strong on goals that are at the centre of voters' agendas. The PD is the party of the left, in particular on the cultural dimension a-la-Kriesi et al. (2006): Europe and rights. This does not appear as a very profitable profile, since, as we have seen above, the salience assigned by voters to cultural progressive goals is generally low.

As a final remark, we can notice that all four major parties (with the partial exception of FI) always show the highest cross-party IY on their top-five IY goals. This is relevant as any given issue is profitable for a party not only if the party has a high IY on that issue, but also if the party ranks first on it, which means that such party is in a better position compared to competitors.

[Table 1 here]

\section{The supply side: Party campaign strategies on Twitter}

We now turn to party campaign strategies, by addressing the supply-side of our Proposition 1, which concerns party strategies' ideological consistency. Table 2 reports, for each of the four major parties, the top-five goals by IE, along with their specific tweet share, and the cross-party IY ranking on that issue. ${ }^{7}$ The configuration of party emphasis has been less ideologically inconsistent than party electorates. Thus, parties have not fully managed to exploit the opportunities actually available to them, by being more anchored to a traditional $20^{\text {th }}$-century conflict-mobilisation strategy. The partial exception is the League, which mostly campaigned on right-wing policies, but also on reducing pension age - a traditional social-democratic economic goal. Conversely, the PD campaigned on economically progressive goals (tax progressivity and bonuses for children), while FI emphasised 
both economic and cultural conservative goals (flat tax and refugees). Finally, the M5S chose a nonideological campaign, as indicated by the fact that it stressed only one positional goal - lowering pension age. ${ }^{8}$

[Table 2 here]

This is an interesting piece of evidence, which leads us to our assessment of Proposition 2 on the supply side. Namely, we are interested in evaluating whether the various parties adopted conflictmobilisation strategies, or problem-solving strategies, assuming that mainstream parties should adopt the latter (contrary to the niche and challenger parties). Table 3 reports, for each party, the overall number of issue-related tweets during the campaign, and its subdivision among positional issues and valence issues. Data show a clear prevalence of positional issues over valence ones (66\% against $34 \%$ ). Hence, parties have prevalently adopted a conflict-mobilisation strategy instead of a problemsolving one.

By looking at single parties, a large variability in the absolute number of tweets emerges: from the 31 issue-related tweets of the M5S to the 368 of the League. This witnesses the presence of different strategies as regards the use of Twitter as a strategic communication tool. While centre-right parties have done a massive use of this social network to flood the potential audience with their messages, other parties (like the M5S and, to a lesser extent, the PD and LEU) are likely to have adopted different strategies, either focusing their campaign on other media sources or using Twitter as a 'press-release'.

Looking more into detail, the League shows a predominant conflict-mobilisation strategy, as expected. ${ }^{10}$ Yet, data display some results contrary to our expectations, as both mainstream parties (FI and PD) show prevalently conflict-mobilisation campaign strategies. These first pieces of evidence reveal a crucial process that took place during the campaign: PD and FI seem to have lost the features of typical mainstream parties. In particular, given its low perceived credibility in solving 
problems, Renzi's party has reacted by reducing the emphasis on shared goals and problem-solving ability.

Finally, the M5S, for which we did not have a definite expectation as it is a challenger with a catch-all appeal and not a niche one, opted for a predominantly problem-solving strategy. Thus, it seems that the M5S has campaigned as a catch-all party, assuming the typical behaviour of a mainstream party, consistently with the high credibility voters attributed to Di Maio's party. A further element makes this strategy consistent with the opportunities available to the M5S. As we have seen, it has an ideologically inconsistent electorate. As a consequence, it might be electorally dangerous to emphasise divisive goals, which might divide its own electorate.

[Table 3 here]

Beyond the assessment of Proposition 1 and Proposition 2, Table 2 allows us to provide a preliminary piece of evidence about the strategicness of the four major Italian parties (which will be properly assessed through the regression analysis presented in the next section), as it highlights, in bold, those issues contemporary present among the five most-emphasised and among the five with the highest IY. In a nutshell, data show that the PD has chosen a less strategic campaign compared to FI and League, with the M5S falling in the middle.

Overall, the data we have presented so far in terms of opportunity configurations and party strategies allow us to draw a final assessment of both demand and supply side of Proposition 2. Table 4 summarizes our results, focussing on whether they are in line with theory-driven expectations for the four main Italian parties. On the demand side, Table 4 confirms the expectations for FI (prevalence of valence profile) and for the League (prevalence of positional profile), but it shows that expectations for the PD (prevalence of positional profile) are not confirmed. On the supply side, the results are in line with expectations for the League (prevalence of positional profile) but not for the FI and PD (prevalence of positional profile in both cases). Finally, for the M5S, for which we did not have a 
specific expectation, due to its mixed nature (clearly challenger but with a catch-all appeal), our findings indicate that its catch-all feature definitely prevails as shown by the predominance of valence issues on both the demand and the supply side.

[Table 4 here]

All in all, the empirical verification of Proposition 2 leads to mixed results. Still, this does not indicate a failure of our issue-yield based analytic framework. Indeed, although contrary to generic theory-driven expectations for mainstream parties, the PD's prevalently positional strategy reveals the adaptation to its actual opportunities (mostly positional, given that it does not appear anymore a credible problem-solver, as we have discussed earlier). This is actually exactly what issue yield theory predicts. However, comparing and contrasting Table 1 with Table 2 suggests that the PD did not emphasize exactly those positional issues on which it had great campaign opportunities, contrary to what the League did. This suggests that, probably, not all parties were strategic to the same extent. The next section provides a systematic verification of the fit of issue yield theory on the campaign strategies of the various Italian parties (Proposition 3).

\section{Theory testing}

In order to provide a formal assessment of whether Italian parties have actually campaigned strategically on Twitter rather than merely reacting to the system-wide public opinion agenda (Proposition 3), we estimated regression models of IE based on two rival predictors: the IY vs. the SS for issue-party combinations. In this section we discuss two analyses: 1) a general model across all parties, which assesses the predominance of either of the two predictors in the strategies of all parties and provides the empirical validation for Proposition 3; 2) the estimation of party-specific models (through interactions), in order to assess which of the two approaches is predominant for each 
party, thus allowing us to compare Italian parties in terms of strategicness, based on the assumption that larger effects of IY imply more strategic behaviour.

In Table 5, we present three different specifications for estimations of Tobit models of IE. In Model 1, we regress IE on IY. In Model 2, we regress IE on SS. Finally, in Model 3, we estimate a full model with both measures. The results are satisfactory. The coefficient for IY is positive and highly statistically significant. IY (measured before the campaign) is a predictor of Twitter emphasis of specific issues during the campaign, with an explained variance of $13 \% .{ }^{11}$ The second model shows that SS has a positive and highly significant effect too, but the explained variance is much smaller (8\%). Furthermore, it should be noticed that these measures have different theoretical (and empirical) ranges. IY has a range $(-1$ to +1$)$ that is twice as large as SS (0 to 1$)$. As a consequence, the higher effect indicated by the IY coefficient compared to the SS coefficient, is actually even higher. Finally, the third model confirms that IY in the Italian context is a better predictor of IE compared to SS, even though the latter is statistically significant as well. Overall, the variance explained by Model 3 (23\%) is slightly less than twice as large as the variance explained by Model 1 and about three times larger than the variance explained by Model 2. Hence, Italian parties, on average, campaigned on Twitter according to IY theory expectations more than they merely reacted to the system-wide agenda. Overall, we find that issue yield theory is confirmed by this empirical analysis of the Italian case. Parties usually strategically emphasise issues which might provide higher electoral returns as calculated by the IY measure (Proposition 3).

[Table 5 here]

In order to verify whether this finding concerning Proposition 3 applies to individual parties and not just in the pooled sample of parties, we estimated party-specific marginal effects for IY and SS on IE (see Table A5 and Figure A2 in Appendix B). ${ }^{12}$ Findings show that, out of the seven parties, all except one have positive and significant marginal effects for IY, in line with our expectations. 
Furthermore, evidence shows that for most parties the coefficient for the marginal effects of IY is higher than that of SS. This is a clear indication that our claim about the importance of issue yield theory in explaining electoral campaigns in contemporary Italy does not come from a single outlier party driving the effect observed in the pooled analysis (Table 5). Rather, it appears as strategicness of campaign emphases in terms of the issue yield framework is a general feature of most Italian parties.

Of course, this general finding does not mean that all parties have been equally strategic. Looking specifically at the four main parties we have focussed so far in terms of issue opportunities and campaign strategies, we are able to highlight noteworthy differences. ${ }^{13}$ The League and FI prove to be mostly strategic, as indicated by the higher marginal effect for IY compared to SS. In particular, Berlusconi's party strategically exploited its issue opportunities by tweeting mostly on the flat tax (39\% of overall tweets, see Table 2), while Salvini's party strategically emphasised anti-immigration goals, the valence goal of making citizens safer from crime, and the left-wing goal of reducing pension age. Conversely, PD and M5S show a prevalence of SS over IY, which is nevertheless positive and significant. $^{14}$

\section{Conclusion}

In this article, we investigated the presence of issue-yield-based campaign strategies among Italian political parties. In this regard, the Italian case was particularly interesting, considering the extraordinary turbulent period the Italian system is experiencing over the past few years in terms of voter's mobility and party system change. In particular, electoral volatility has been so high that an unprecedented number of voters are on the market and can therefore be conquered by parties adopting different strategies in the electoral campaign (Chiaramonte et al. 2018). Furthermore, no other country as Italy has witnessed the rise of so successful new parties in recent years (Emanuele and Chiaramonte 2018). Moreover, these have explicitly challenged the $20^{\text {th }}$-century left-right-based party competition (Bordignon and Ceccarini 2013). For these reasons, Italy appears as a paradigmatic case 
of a system in which parties, in line with issue yield theory, are likely to campaign through a strategic combination of profitable left- and right-wing issues exactly as a consequence of the disruption of this traditional conflict line experienced in the last years.

In particular, we have shown three important empirical findings related to our propositions. First, we have highlighted the ideological inconsistency of the different party electorates, whose preferences combine left-wing positions on the economy and right-wing positions on immigration. Nevertheless, parties have twitted more consistently with their traditional left-right orientation. The only, though partial, exception is the League, which emphasised also an economic left-wing goal along with the classic right-wing goals on the cultural dimension. Furthermore, the M5S opted for a non-ideological campaign, by focusing mainly on valence issues.

This leads us to our second main empirical finding: Italian parties have adopted mostly conflict-mobilisation strategies based on positional issues, rather than problem solving strategies based on valence issues. Behind this general picture, our theory-driven expectations predicting problem-solving strategies for mainstream parties and conflict-mobilisation strategies for niche and challenger parties are not fully confirmed. Indeed, mainstream parties (PD and FI) did not campaign prevalently on problem solving, contrary to what we expected. Finally, as anticipated above, the M5S, for which we did not have any specific expectation (since it is a challenger party but with a catch-all appeal), adopted a problem-solving strategy. Moreover, our data indicate some reasons why these strategies were actually pursued. In particular, the emphasis the M5S placed on valence issues is coherent with its nature of a post-ideological catch-all party - which might lose votes campaigning on too divisive and polarizing issues - and probably it is also related to the low credibility mainstream parties (FI and especially the PD) had on several valence issues. This is a clear sign of the increasing mistrust and dissatisfaction Italian voters have towards the two mainstream parties that have alternated in government in the last decade and the dissatisfaction for their record in office in a period marked by the Great economic recession (Hernández and Kriesi 2016). 
Third, our explanatory analyses show that, as expected, issue yield is better than systemic salience in predicting party emphases during the electoral campaign. Nevertheless, this general finding presents some exceptions. For the League, FI, FDI, and +EUR party strategies were mostly driven by electoral risks/opportunities considerations rather than simply mirroring the system-wide issue agenda, whereas for the two biggest parties (PD and M5S) both issue yield and systemic salience show positive and significant effects (although the latter is larger). LEU represents the only sharp deviation from this general pattern, as no significant effect for issue yield emerges.

Furthermore, our investigation can shed light on the link between party strategies and electoral performances. Interestingly enough, it appears that issue yield related strategies provide an indication of the successfulness of the electoral performance for the various parties, though only to a partial extent. In particular, 'strategicness' seems to have rewarded the party that made the greatest electoral gains - the League (rocketing from $4.1 \%$ in 2013 to $17.4 \%$ in 2018) and, to a lesser extent, FDI (which more than doubled its vote share). At the same time, it is also true that the least strategic parties on Twitter (the PD and especially LEU) have experienced electoral defeats. However, evidence shows also that strategicness does not necessarily lead to good electoral results, as in the case of FI. Despite being very strategic on Twitter, FI experienced a historical defeat. In this regard, it is likely that the party was damaged by other reasons. As a typical personalised party (Calise 2015), whose support relies mainly on the charismatic leadership of Berlusconi, FI suffered from the fact that its leader was not eligible due to its past criminal conviction for tax fraud. In addition, Berlusconi, due to aging and increasing health concerns, was less able than in the past to run an intensive and effective campaign neither in the squares nor on TV. The latter, for FI voters, is by far a more relevant source of information compared to Twitter and, more generally, to the internet (De Sio 2013). In a nutshell, the association between party strategy and electoral performance is far from perfect, and able to predict only a small fraction of the variance in electoral performance as properly shown by De Sio and Weber in their cross-country comparative analysis included in this issue. This is because Twitter as a pressrelease (Kreiss 2016; Parmelee and Bichard 2011) does not work in the same way for all parties (e.g., 
the M5S on the basic income), and, above all, many other non-policy factors are relevant (i.e. structural determinants, party identification, state of the economy, incumbency factor, leadership effects and so on).

At any rate, further research is due in order to give a more systematic explanation of how issue yield theory, in addition to accounting for party campaign strategies, interacts with other non-policy factors in the explanation of parties' electoral performances. Still, it looks quite clear that the context Italian parties live in is transforming, and that they need to adapt their strategies accordingly, if they want to be electorally rewarded. As Bob Dylan said, “you better start swimmin’ or you'll sink like a stone for the times they are a-changin'."

\section{Endnotes}

\footnotetext{
${ }^{1}$ For the M5S we do not have definite expectations, as it is a challenger party with a catch-all appeal and not a niche one.

${ }^{2}$ Detailed question wording for all variables of interest is reported in Appendix C.

${ }^{3}$ Party credibility was deliberately a multiple-choice item, to limit endogeneity on party preference. For the general research design and measurement strategy, see D'Alimonte et al. (in this issue). Furthermore, credibility appears more suitable than the well-known notion of competence (Green and Jennings 2012), which is generally applied to measure issue ownership and to specifically tackle valence goals. Conversely, credibility also applies to positional goals, thus being more useful for the study at hand which includes both valence and positional issues. Indeed, issue yield can be seen as clearly related to issue ownership theory (Petrocik 1996), as it provides a different operationalization of a relatively related concept. As such, IY can be seen subsuming and generalizing issue ownership though a continuous, dynamic
} measure.

${ }^{4}$ Fleiss et al. (2013) guidelines to interpret the meaning of the kappa statistic consider values over 0.75 as excellent.

5 The rationale supporting this methodological choice is that, particularly when a relevant number of party-issue combinations with 0 emphasis is present ( $38 \%$ in the present study), for extremely unfavourable issues parties might decrease emphasis even below 0 if that were possible. As a consequence, emphasis can be considered as censored at 0 .

${ }^{6}$ The rationale is that two goals on which a given party has the same IY score do not yield the same competitive advantage according to whether different parties have even higher IY scores on that goal or not.

${ }^{7}$ Tables A1 and A2 in Appendix B report the complete IY and IE configuration for each of the parties, for valence and positional issues, respectively.

${ }^{8}$ This is a piece of evidence that Twitter might not be a perfect measure of the actual campaign. Indeed, albeit not emphasised on Twitter, the introduction of a basic income was at the core of the M5S campaign on other media sources (on Facebook and in television). 
${ }^{9}$ The underlying idea is that, just like in a press-release, parties use Twitter to communicate their desired message to media (Kreiss 2016; Parmelee and Bichard 2011). In this respect, the relatively sparse communication style of some parties is a confirmation of the press-release assumption: under strong media attention, even a single daily tweet will have a very large media impact.

${ }^{10}$ The same is true for two additional niche parties FDI and +EUR. Conversely, LEU adopted a problem-solving strategy (see Table A3 and A4 in Appendix B reporting, respectively, the top-five IY goals and the top-five goals by IE for FDI, LEU and +EUR).

11 The measure reported as VarExp is an innovative goodness of fit statistic based on RMSE, to avoid problems for comparing models through 'pseudo-Rsquared' in Tobit regression. It can be interpreted in terms of variance explained (see De Sio and Weber in this issue for details).

${ }^{12}$ A positive and significant IY marginal effect implies that the party behaves strategically, emphasizing goals with high IY (regardless of the low or high salience of the issue according to public opinion). If the SS marginal effect is higher than IY, this means that for party issue emphasis general public opinion priorities prevail over strategic considerations. As an additional robustness check, we interacted each of the two effects separately to detect collinearity, creating two different marginal plots for marginal effects of IY and SS on IE. Results are substantially similar to those presented in Figure A2.

${ }^{13}$ Our data also provide analogous information about three minor Italian parties: FDI, +EUR, and LEU. FDI and +EUR prove to be the particularly strategic parties, whereas LEU is the only non-strategic party, as indicated by the nonsignificant (and negative) marginal effect for IY. This implies that not only the party merely reacted to the system-wide agenda, but also it campaigned by emphasizing issues on which it had poor opportunities.

${ }^{14}$ For the M5S this can be explained by its tendency to follow public opinion priorities, as well as by the fact that their campaign on Twitter, contrary to that on other media, did not focus on the basic income issue, the signature proposal of the party platform which potentially could provide a high electoral yield. 


\section{Disclosure statement}

No potential conflict of interest was reported by the authors.

\section{Notes on contributors}

Vincenzo Emanuele is Assistant Professor in the Political Science Department at LUISS - Guido Carli in Rome. He is a member of CISE, ITANES, and co-Chair of the Research Network on Political Parties, Party Systems and Elections of the Council for European Studies. His research focuses mainly on party system change and has appeared, among others, in Comparative Political Studies, Party Politics, South European Society and Politics, Government and Opposition, and Regional and Federal Studies. His monograph Cleavages, institutions, and competition. Understanding vote nationalization in Western Europe (1965-2015) is published by Rowman and Littlefield/ECPR Press (2018).

Nicola Maggini is a Research Fellow in the Department of Legal Sciences of the University of Florence and a member of CISE (Italian Centre for Electoral Studies). His main research interests are socio-political attitudes, electoral systems, voting behaviour and party competition in comparative perspective. He has published in Italian and international journals and is the author of Young People's Voting Behavior in Europe. A Comparative Perspective (Palgrave Macmillan, 2016).

Aldo Paparo is a Research Fellow in the Department of Political Science of the LUISS - Guido Carli and a member of CISE (Italian Centre for Electoral Studies). His main areas of interest are electoral systems, political systems and electoral behaviour, with particular attention to the local level. He has co-edited numerous volumes of CISE Dossier series; and published on Quaderni dell'Osservatorio Elettorale, Contemporary Italian Politics, Monkey Cage - among others. He was also co-author of a chapter in Terremoto Elettorale (Il Mulino, 2014).

\section{ORCID}

Vincenzo Emanuele http://orcid.org/0000-0002-1589-5025

Nicola Maggini http://orcid.org/0000-0002-6844-1641

Aldo Paparo http://orcid.org/0000-0003-3542-3145

\section{References}

Ansolabehere, Stephen, and Shanto Iyengar (1994). 'Riding the Wave and Claiming Ownership over Issues: The Joint Effects of Advertising and News Coverage in Campaigns', Public Opinion Quarterly, 58:3, 335-357.

Bartolini, Stefano, and Peter Mair (1990). Identity, Competition, and Electoral Availability: The Stability of European Electorates, 1885-1985. Cambridge: Cambridge University Press.

Biorcio, Roberto (2010). 'Gli Antecedenti Politici Della Scelta Di Voto: L'identificazione Di Partito e l'autocollocazione Sinistra-Destra', in Paolo Bellucci and Paolo Segatti (eds.), Votare in Italia. Bologna: Il Mulino, 187-212

Bordignon, Fabio, and Luigi Ceccarini (2013). 'Five Stars and a Cricket. Beppe Grillo Shakes Italian Politics', South European Society and Politics, 18:4, 427-449.

Calise, Mauro (2015). 'The Personal Party: An Analytical Framework', Italian Political Science Review / Rivista Italiana Di Scienza Politica, 45:3, 301-15. https://doi.org/10.1017/ipo.2015.18. 
Carmines, Edward G., and James A. Stimson (1980). 'The Two Faces of Issue Voting', American Political Science Review, 74:1, 78-91.

Chiaramonte, Alessandro, and Lorenzo De Sio, eds. (2014). Terremoto Elettorale. Le Elezioni Politiche Del 2013. Bologna: Il Mulino.

Chiaramonte, Alessandro, Vincenzo Emanuele, Nicola Maggini, and Aldo Paparo (2018). 'Populist Success in a Hung Parliament: The 2018 General Election in Italy', South European Society and Politics, https://doi.org/10.1080/13608746.2018.1506513.

Clarke, Harold D., David Sanders, Marianne C. Stewart, and Paul F. Whiteley (2009). Performance Politics and the British Voter. New York: Cambridge University Press.

D'Alimonte, Roberto, Lorenzo De Sio, and Mark N. Franklin. submitted manuscript. 'Dimensions and Dynamics of Issue Politics: A Conceptual Framework and a Research Design', West European Politics, submitted manuscript.

Dalton, Russell J (1984). 'Cognitive Mobilization and Partisan Dealignment in Advanced Industrial Democracies', The Journal of Politics, 46:01, 264-284.

De Sio, Lorenzo (2013). 'A “Media Divide" in the Vote of February 25?', in Lorenzo De Sio, Vincenzo Emanuele, Nicola Maggini, and Aldo Paparo (eds.), The Italian General Election of 2013: A Dangerous Stalemate?. Rome: Centro Italiano Studi Elettorali, 69-72.

(2014). 'Where Does Renzi’s Victory Come from?', in Lorenzo De Sio, Vincenzo Emanuele, and Nicola Maggini (eds.), The European Parliament Elections of 2014. Rome: Centro Italiano Studi Elettorali, 117-24.

De Sio, Lorenzo, Andrea De Angelis, and Vincenzo Emanuele (2018). 'Issue Yield and Party Strategy in Multiparty Competition', Comparative Political Studies, 51:9, 1208-38.

De Sio, Lorenzo, Mark N. Franklin, and Till Weber (2016). 'The Risks and Opportunities of Europe: How Issue Yield Explains (Non-) Reactions to the Financial Crisis', Electoral Studies, 44, 483-491.

De Sio, Lorenzo, and Romain Lachat. submitted manuscript. 'Making Sense of Party Strategy Innovation: Challenge to Ideology and Conflict Mobilisation as Dimensions of Party Competition', West European Politics, submitted manuscript.

De Sio, Lorenzo, and Till Weber. submitted manuscript. 'Issue Yield, Campaign Communication, and Electoral Performance: A Six-Country Comparative Analysis', West European Politics, submitted manuscript.

(2014). 'Issue Yield: A Model of Party Strategy in Multidimensional Space', American Political Science Review, 108:4, 870-885.

Dogan, Mattei (1967). 'Political Cleavage and Social Stratification in France and Italy', in Seymour Martin Lipset and Stein Rokkan (eds.), Party Systems and Voter Alignments: Cross-National Perspectives. New York: Free Press, 129-95.

Emanuele, Vincenzo, and Alessandro Chiaramonte (2018). 'A Growing Impact of New Parties: Myth or Reality? Party System Innovation in Western Europe after 1945', Party Politics, 24:5, 47587.

Fleiss, Joseph L., Bruce Levin, and Myunghee Cho Paik (2013). Statistical Methods for Rates and Proportions. New York: John Wiley \& Sons.

Franklin, Mark N. (1992). 'The Decline of Cleavage Politics', in Mark N. Franklin, Thomas T. Mackie, and Henry Valen (eds.), Electoral Change: Responses to Evolving Social and Attitudinal Structures in Western Countries. Cambridge: Cambridge University Press, 383405.

Fuchs, Dieter, and Hans-Dieter Klingemann (1990). 'The Left-Right Schema', in M. Kent Jennings and Jan W. van Deth (eds.), Continuities in Political Action: A Longitudinal Study of Political Orientations in Three Western Democracies. Berlin/New York: Walter de Gruyter, 203-234.

Green, Jane, and Will Jennings (2012). 'Valence as Macro-Competence: An Analysis of Mood in Party Competence Evaluations in Great Britain', British Journal of Political Science, 42:2, 311-343. 
Green-Pedersen, Christoffer (2007). 'The Growing Importance of Issue Competition: The Changing Nature of Party Competition in Western Europe', Political Studies, 55:3, 607-628.

Hernández, Enrique, and Hanspeter Kriesi (2016). 'The Electoral Consequences of the Financial and Economic Crisis in Europe', European Journal of Political Research, 55:2, 203-224.

Kaplan, Noah, David K. Park, and Travis N. Ridout (2006). 'Dialogue in American Political Campaigns? An Examination of Issue Convergence in Candidate Television Advertising', American Journal of Political Science, 50:3, 724-36. https://doi.org/10.1111/j.15405907.2006.00212.x.

Kirchheimer, Otto (1966). 'The Transformation of the Western European Party Systems', in Joseph LaPalombara and Myron Weiner (eds.), Political Parties and Political Development. Princeton, NJ: Princeton University Press, 177-200.

Kreiss, Daniel (2016). 'Seizing the Moment: The Presidential Campaigns' Use of Twitter during the 2012 Electoral Cycle', New Media \& Society, 18:8, 1473-1490.

Kriesi, Hanspeter, Edgar Grande, Romain Lachat, Martin Dolezal, Simon Bornschier, and Timotheos Frey (2006). 'Globalization and the Transformation of the National Political Space: Six European Countries Compared', European Journal of Political Research, 45:6, 921-956.

Maggini, Nicola (2014). 'Understanding the Electoral Rise of the Five Star Movement in Italy', Czech Journal of Political Science, 21:1, 37-59.

Meguid, Bonnie M. (2005). 'Competition between Unequals: The Role of Mainstream Party Strategy in Niche Party Success', American Political Science Review, 99:3, 347-359.

Mudde, Cas (2007). Populist Radical Right Parties in Europe. Vol. 22. 8. Cambridge: Cambridge University Press.

(2011). 'Radical Right Parties in Europe: What, Who, Why?', Participation, 35:1, 12-15.

Parmelee, John H., and Shannon L. Bichard (2011). Politics and the Twitter Revolution: How Tweets Influence the Relationship between Political Leaders and the Public. Lanham, MD: Lexington Books.

Petrocik, John R. (1996). 'Issue Ownership in Presidential Elections, with a 1980 Case Study', American Journal of Political Science, 825-850.

Sani, Giacomo, and Giovanni Sartori (1978). 'Frammentazione, Polarizzazione e Cleavages: Democrazie Facili e Difficili', Italian Political Science Review/Rivista Italiana Di Scienza Politica, 8:3, 339-361.

Steenbergen, Marco R., and David J. Scott (2004). 'Contesting Europe? The Salience of European Integration as a Party Issue', in Gary Marks and Marco R. Steenbergen (eds.), European Integration and Political Conflict. Cambridge: Cambridge University Press, 165-92.

Stokes, Donald E. (1963). 'Spatial Models of Party Competition', The American Political Science Review, 57:2, 368-77.

Tarchi, Marco (2018). 'Voters without a Party: The "Long Decade" of the Italian Centre-Right and Its Uncertain Future', South European Society and Politics, 23:1, 147-62.

Tronconi, Filippo (2009). I Partiti Etnoregionalisti. La Politica Dell'identità Territoriale in Europa Occidentale. Bologna: Il Mulino.

Van de Wardt, Marc, Catherine E. De Vries, and Sara B. Hobolt (2014). 'Exploiting the Cracks: Wedge Issues in Multiparty Competition', The Journal of Politics, 76:4, 986-999.

Wagner, Markus (2012). 'When Do Parties Emphasise Extreme Positions? How Strategic Incentives for Policy Differentiation Influence Issue Importance', European Journal of Political Research, 51:1, 64-88. https://doi.org/10.1111/j.1475-6765.2011.01989.x. 


\section{Appendix A - Calculation of Issue Yield}

NOTE: this is an excerpt from a separate article in this same special issue.

The issue yield summary index is a summary measure (calculated according to a nonlinear expression) expressing the combination of electoral risks and opportunities that each issue (for positional issue: each side on an issue) offers to a party. In its first formulation issue yield was calculated as follows. Let:

$\mathrm{i}=$ proportion of electorate supporting a policy;

$\mathrm{p}=$ proportion of electorate supporting a party;

$\mathrm{f}=$ proportion of electorate supporting both;

Then (through geometric reasoning: see De Sio and Weber 2014: 876-878):

$$
\text { scaled issue yield }=\frac{f-i p}{p(1-p)}+\frac{i-p}{1-p}
$$

This paper uses an updated formulation, relying on a new explicit measurement of party credibility, where all such components are weighted by such party credibility, thus allowing a generalisation to valence issues.

Let:

cred $=$ party credibility on the goal in the electorate at large intcred $=$ party credibility on the goal within the party base

Then

$$
\text { updatedyield }=\frac{(f-i p) \text { intcred }}{p(1-p)}+\frac{(i-p) \text { cred }}{1-p}
$$

(Note that intcred has to be replaced with 1-intcred if (f-ip) is lower than 0 (goal is supported in the party less than in the whole sample). 
[Figure A1 here]

[Table A1 here]

[Table A2 here]

[Table A3 here]

[Table A4 here]

[Table A5 here]

[Figure A2 here] 


\section{Appendix C-Question wordings}

\section{Positions on positional issues}

Now we'd like to know your views of what should be done on various issues. How would you place your views on this scale, where 1 means you agree completely with the statement on the left, and 6 means you agree completely with the statement on the right? If your views fall somewhere in between, you can choose any number in between.

What do you think should be done?

Please choose the appropriate response for each item:
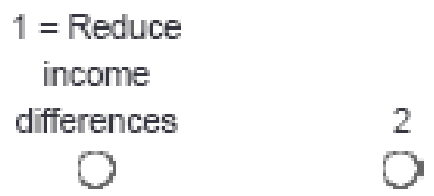

Increase freedom for enterprise, making it easier to hire and fire Keep current law on pension age Scrap the cost of university tuition fees Keep tax progressivity on income (who earns more has a higher tax rate)

Do not introduce the hourly minimum wage

Introduce a basic income for those living in poverty

Intensify the fight against tax evasion Increase economic bonuses to families with children

Limit economic globalization

Stay in the Euro

Leave in the EU

Make the EU economic policies more flexible

Make citizenship for regular immigrants' sons easier Restrict access to welfare benefits for immigrants

Continue to accept refugees like now

Keep current legislation on the End-oflife

Abolish same-sex unions

Legalise soft drugs

Keep mandatory requirements for vaccines

Legalise and regulate prostitution

Decriminalize the excess of self-defence

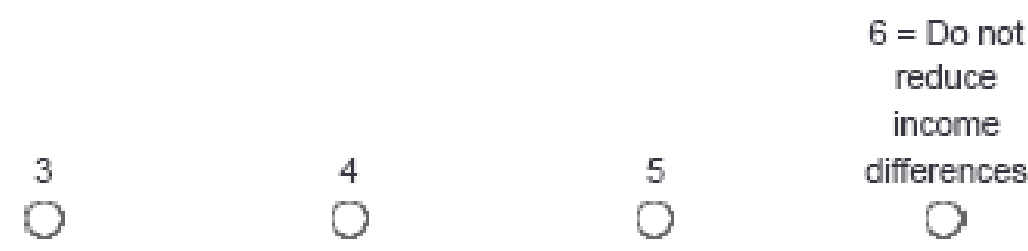

Reduce freedom of enterprise, making it harder to hire and fire Lower pension age

Keep the present cost of university tuition fees Introduce a flat tax (pre-fixed rate of income tax, regardless of the income)

Introduce the hourly minimum wage

Do not introduce a basic income for those living in poverty

Do not intensify the fight against tax evasion

Do not increase economic bonuses to families with children

Promote economic globalization

Leave the Euro Stay in the EU

Keep EU economic austerity

Keep current legislation on citizenship for immigrants' sons

Keep current levels of access to welfare benefits for immigrants

Limit the number of refugees

Abolish current legislation on the End-of-life

Keep same-sex unions

Keep soft drugs illegal

Abolish mandatory requirements for vaccines

Keep current legislation on prostitution Keep current legislation on the excess of selfdefence 


\section{List of valence issues}

Fight unemployment

Fight corruption

Support economic growth

Protect Italy from terrorist attacks

Make Italy count more in Europe

Reduce poverty in Italy

Make citizens safer from crime

Reduce the costs of politics

Ensure the good functioning of healthcare system

Fight pollution and disruption of territory

Improve Italian education

Renew Italian politics

\section{Credibility (for both valence and preferred positional goals)}

Which parties do you think are credible for achieving [this goal]?

Please choose all that apply:

- Partito Democratico

- Movimento Cinque Stelle

○ Forza Italia

○ Lega

- Fratelli d'Italia

- Liberi e Uguali

○ Più Europa

\section{Priority (for both valence and preferred positional goals)}

Do you think that achieving [this goal] should have a...

Please choose only one of the following:

- High priority

$\circ$ Average priority

- Low priority 


\section{List of tables}

Table 1. Top-5 Issue Yield goals for major Italian parties (valence issues in italics).

\begin{tabular}{|c|c|c|c|}
\hline Party & Goal & IY & $\begin{array}{c}\text { IY } \\
\text { Cross- } \\
\text { party } \\
\text { ranking }\end{array}$ \\
\hline \multirow{5}{*}{ 㝏 } & Stay in the Euro & 0.56 & 1 \\
\hline & Stay in the EU & 0.46 & 1 \\
\hline & Make citizenship for regular immigrants' sons easier & 0.43 & 1 \\
\hline & Keep mandatory requirements for vaccines & 0.43 & 1 \\
\hline & Keep same-sex unions & 0.34 & 1 \\
\hline \multirow{5}{*}{$\sum^{n}$} & Reduce the costs of politics & 0.41 & 1 \\
\hline & Introduce a basic income for those living in poverty & 0.38 & 1 \\
\hline & Renew Italian politics & 0.32 & 1 \\
\hline & Fight corruption & 0.30 & 1 \\
\hline & Reduce poverty in Italy & 0.29 & 1 \\
\hline \multirow{5}{*}{ 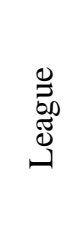 } & Limit the number of refugees & 0.57 & 1 \\
\hline & Restrict access to welfare benefits for immigrants & 0.48 & 1 \\
\hline & Keep current legislation on citizenship for immigrants' sons & 0.42 & 1 \\
\hline & Decriminalise excess of self-defence & 0.40 & 1 \\
\hline & Make citizens safer from crime & 0.36 & 1 \\
\hline \multirow{5}{*}{$\vec{I}$} & Introduce a flat tax & 0.24 & 1 \\
\hline & Limit the number of refugees & 0.24 & 3 \\
\hline & Support economic growth & 0.23 & 1 \\
\hline & Protect Italy from terrorist attacks & 0.21 & 2 \\
\hline & Fight unemployment & 0.21 & 2 \\
\hline
\end{tabular}


Table 2. Top-5 goals by Issue Emphasis on Twitter for major Italian parties (valence issues in italics).

Party Goal $\quad$ IE $\begin{gathered}\text { IY cross- } \\ \text { party } \\ \text { ranking }\end{gathered}$

\begin{tabular}{|c|c|c|c|}
\hline \multirow{5}{*}{$\hat{2}$} & Support economic growth & 0.14 & 3 \\
\hline & Fight unemployment & 0.13 & 3 \\
\hline & Keep tax progressivity on income & 0.12 & 1 \\
\hline & Make citizens safer from crime & 0.07 & 5 \\
\hline & Increase economic bonuses to families with children & 0.07 & 1 \\
\hline \multirow{5}{*}{$\stackrel{n}{\Sigma}$} & Fight pollution and disruption of territory & 0.32 & 1 \\
\hline & Improve Italian education & 0.26 & 1 \\
\hline & Ensure the good functioning of healthcare system & 0.13 & 1 \\
\hline & Lower pension age & 0.06 & 2 \\
\hline & Renew Italian politics & 0.06 & 1 \\
\hline \multirow{5}{*}{ 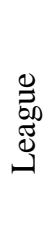 } & Limit the number of refugees & 0.27 & 1 \\
\hline & Lower pension age & 0.15 & 1 \\
\hline & Introduce a flat tax & 0.09 & 2 \\
\hline & Make citizens safer from crime & 0.06 & 1 \\
\hline & Decriminalise excess of self-defence & 0.05 & 1 \\
\hline \multirow{5}{*}{$\vec{I}$} & Introduce a flat tax & 0.39 & 1 \\
\hline & Limit the number of refugees & 0.14 & 3 \\
\hline & Fight unemployment & 0.14 & 2 \\
\hline & Reduce poverty in Italy & 0.10 & 3 \\
\hline & Support economic growth & 0.07 & 1 \\
\hline
\end{tabular}

Note: goals that were also among the top-5 for IY are in bold. 
Table 3. Counts of Twitter Contents: Positional, Valence, Non-Issue Contents.

\begin{tabular}{|c|c|c|c|c|c|c|}
\hline \multirow[t]{2}{*}{ Party } & \multicolumn{2}{|c|}{ Positional issues } & \multicolumn{2}{|c|}{ Valence issues } & \multicolumn{2}{|c|}{ Total issue contents } \\
\hline & $\mathrm{N}$ & $\%$ & $\mathrm{~N}$ & $\%$ & $\mathrm{~N}$ & $\%$ \\
\hline PD & 43 & 51.2 & 41 & 48.8 & 84 & 100 \\
\hline M5S & 4 & 12.9 & 27 & 87.1 & 31 & 100 \\
\hline League & 388 & 82.6 & 82 & 17.4 & 470 & 100 \\
\hline FI & 215 & 58.4 & 153 & 41.6 & 368 & 100 \\
\hline Minor parties & 187 & 584 & 133 & 41.6 & 320 & 100 \\
\hline Total & 837 & 65.8 & 436 & 34.2 & 1,273 & 100 \\
\hline
\end{tabular}


Table 4. Summary of expectations and findings for the prevalence of positional or valence issues for major Italian parties.

\begin{tabular}{|c|c|c|c|}
\hline Party & Expectation & Findings: Demand side & Findings: Supply side \\
\hline PD & Valence & Positional & (slightly) Positional \\
\hline M5S & No clear expectation & Valence & Valence \\
\hline League & Positional & Positional & Positional \\
\hline FI & Valence & Valence & Positional \\
\hline
\end{tabular}


Table 5. Issue strategies in Italy: Effects of Issue Yield and Systemic Salience on Issue Emphasis.

\begin{tabular}{lccc}
\hline & Model 1 & Model 2 & Model 3 \\
& IY & SS & IY and SS \\
\hline IY & $0.28^{* * *}$ & & $0.30^{* * * *}$ \\
& $(0.08)$ & & $(0.07)$ \\
SS & & $0.21^{* * *}$ & $0.22^{* * *}$ \\
& & $(0.06)$ & $(0.03)$ \\
Constant & & & $-0.22^{* * *}$ \\
& $-0.05^{* *}$ & $-0.16^{* *}$ & $(0.04)$ \\
Sigma Constant & $(0.02)$ & $(0.05)$ & $0.08^{* * *}$ \\
& & & $(0.01)$ \\
\hline$N$ & $0.08^{* * *}$ & $0.09^{* * *}$ & \\
AIC & $(0.01)$ & $(0.01)$ & 238 \\
BIC & & & -148.97 \\
VarExp & 238 & 238 & -135.08 \\
Nig & -127.23 & -119.93 & 0.225 \\
\hline
\end{tabular}

Note: Table entries represent coefficients for the Tobit regression of IE on the hypothesised predictors (estimation based on robust standard errors, with observations clustered by party). The dependent variable is censored at 0 . Standard errors reported in parentheses. ${ }^{*} \mathrm{p}<0.05,{ }^{* * *} \mathrm{p}<0.01,{ }^{* * *} \mathrm{p}<0.001$. 
Table A1. Complete configurations of IY and IE for Italian parties on valence issues (Rank indicates cross-party IY ranking on that goal).

\begin{tabular}{|c|c|c|c|c|c|c|c|c|c|c|c|c|c|c|c|c|c|c|c|c|c|}
\hline \multirow[b]{2}{*}{ Goal } & \multicolumn{3}{|c|}{ FDI } & \multicolumn{3}{|c|}{ FI } & \multicolumn{3}{|c|}{ LEU } & \multicolumn{3}{|c|}{ League } & \multicolumn{3}{|c|}{ M5S } & \multicolumn{3}{|c|}{ PD } & \multirow[b]{2}{*}{ IY } & \multicolumn{2}{|c|}{ +EUR } \\
\hline & IY & Rank & IE & IY & Rank & $\mathrm{IE}$ & IY & Rank & IE & IY & Rank & IE & IY & Rank & IE & IY & Rank & $\mathrm{IE}$ & & Rank & $\mathrm{IE}$ \\
\hline Fight unemployment & 0.12 & 5 & 0.03 & 0.21 & 2 & 0.14 & 0.08 & 6 & 0.03 & 0.19 & 4 & 0.04 & 0.25 & 1 & 0.00 & 0.21 & 3 & 0.13 & 0.06 & 7 & 0.00 \\
\hline Fight corruption & 0.08 & 6 & 0.00 & 0.10 & 4 & 0.00 & 0.09 & 5 & 0.00 & 0.14 & 3 & 0.00 & 0.30 & 1 & 0.03 & 0.16 & 2 & 0.00 & 0.07 & 7 & 0.00 \\
\hline Support economic growth & 0.11 & 5 & 0.01 & 0.23 & 1 & 0.07 & 0.07 & 6 & 0.02 & 0.18 & 4 & 0.03 & 0.22 & 2 & 0.03 & 0.22 & 3 & 0.14 & 0.06 & 7 & 0.10 \\
\hline Protect Italy from terrorist attacks & 0.17 & 5 & 0.02 & 0.21 & 2 & 0.00 & 0.07 & 7 & 0.00 & 0.30 & 1 & 0.00 & 0.19 & 3 & 0.00 & 0.19 & 4 & 0.00 & 0.07 & 6 & 0.00 \\
\hline Make Italy count more in Europe & 0.10 & 6 & 0.01 & 0.20 & 3 & 0.04 & 0.06 & 7 & 0.00 & 0.18 & 4 & 0.02 & 0.21 & 1 & 0.00 & 0.21 & 2 & 0.00 & 0.10 & 5 & 0.05 \\
\hline Reduce poverty in Italy & 0.08 & 6 & 0.02 & 0.15 & 3 & 0.10 & 0.09 & 5 & 0.03 & 0.15 & 4 & 0.01 & 0.29 & 1 & 0.03 & 0.18 & 2 & 0.04 & 0.06 & 7 & 0.00 \\
\hline Make citizens safer from crime & 0.20 & 2 & 0.22 & 0.19 & 3 & 0.07 & 0.06 & 6 & 0.01 & 0.36 & 1 & 0.06 & 0.19 & 4 & 0.00 & 0.14 & 5 & 0.07 & 0.04 & 7 & 0.01 \\
\hline Reduce the costs of politics & 0.06 & 5 & 0.00 & 0.09 & 3 & 0.00 & 0.03 & 7 & 0.00 & 0.10 & 2 & 0.00 & 0.41 & 1 & 0.00 & 0.09 & 4 & 0.00 & 0.04 & 6 & 0.00 \\
\hline Ensure the good functioning of healthcare system & 0.11 & 5 & 0.01 & 0.17 & 3 & 0.00 & 0.07 & 6 & 0.14 & 0.17 & 4 & 0.00 & 0.21 & 1 & 0.13 & 0.18 & 2 & 0.02 & 0.05 & 7 & 0.02 \\
\hline Fight pollution and disruption of territory & 0.07 & 7 & 0.08 & 0.11 & 3 & 0.01 & 0.10 & 5 & 0.21 & 0.11 & 4 & 0.00 & 0.27 & 1 & 0.32 & 0.16 & 2 & 0.04 & 0.09 & 6 & 0.02 \\
\hline Improve Italian education & 0.09 & 5 & 0.04 & 0.17 & 3 & 0.00 & 0.08 & 6 & 0.09 & 0.14 & 4 & 0.02 & 0.21 & 1 & 0.26 & 0.18 & 2 & 0.05 & 0.08 & 7 & 0.02 \\
\hline Renew Italian politics & 0.07 & 5 & 0.01 & 0.10 & 4 & 0.00 & 0.05 & 6 & 0.03 & 0.12 & 2 & 0.00 & 0.32 & 1 & 0.06 & 0.11 & 3 & 0.00 & 0.04 & 7 & 0.05 \\
\hline
\end{tabular}


Table A2. Complete configurations of IY and IE for Italian parties on positional issues ( $\mathrm{R}$ indicates cross-party IY ranking on that goal).

Goal

Reduce income differences

Limit economic globalization

Stay in the Euro

Stay in the EU

Make the EU economic policies more flexible

Do not reduce income differences

Promote economic globalization

Leave the Euro

Leave the Euro

Keep EU economic austerity

Make citizenship for regular immigrants' sons easier

Keep current legislation on citizenship for immigrants' sons Keep current levels of access to welfare benefits for immigrants

Restrict access to welfare benefits for immigrants

Continue to accept refugees like now

Keep current legislation on the End-of-life Limit the number of refugees Abolish current legislation on the End-of-life

Keep same-sex unions

Legalise soft drugs

Abolish same-sex unions

Keep soft drugs illegal

Reduce freedom of enterprise, making it harder to hire and fire

Increase freedom for enterprise, making it easier to hire and fire Keep mandatory requirements for vaccines

Abolish mandatory requirements for vaccines

Legalise and regulate prostitution

Keep current legislation on the excess of self-defence

Decriminalize the excess of self-defence

Lower pension age

Keep current law on pension age

Keep the present cost of university tuition fees

Scrap the cost of university tuition fees

Keep progressive taxation on income

Introduce the hourly minimum wage

Introduce a flat tax

Do not introduce the hourly minimum wage Introduce a basic income for those living in poverty

Do not introduce a basic income for those living in poverty Intensify the fight against tax evasion

Do not intensify the fight against tax evasion Increase economic bonuses to families with children

Do not increase economic bonuses to families with children

\section{\begin{tabular}{lcl}
\multicolumn{3}{c}{ FDI } \\
\hline IY & R IE
\end{tabular}}

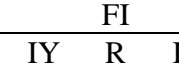

$\begin{array}{lll}0.07 & 1 & 0.00\end{array}$

$\begin{array}{lll}0.11 & 3 & 0.05\end{array}$

$\begin{array}{lll}0.04 & 3 & 0.00\end{array}$

$\begin{array}{lll}0.10 & 2 & 0.00\end{array}$

$\begin{array}{lll}0.16 & 3 & 0.01\end{array}$

$\begin{array}{lll}0.23 \quad 2 & 0.00\end{array}$

$\begin{array}{lll}0.29 & 2 & 0.01\end{array}$

$\begin{array}{lll}0.34 & 2 & 0.22\end{array}$

$\begin{array}{lll}0.08 & 1 & 0.00\end{array}$

$\begin{array}{lll}0.19 & 1 & 0.00\end{array}$

$\begin{array}{lll}0.12 & 3 & 0.00\end{array}$

$\begin{array}{lll}0.11 & 3 & 0.00\end{array}$

$\begin{array}{lll}0.04 & 2 & 0.00\end{array}$

$\begin{array}{lll}0.15 & 2 & 0.02\end{array}$

$\begin{array}{lll}0.31 & 2 & 0.09\end{array}$

$\begin{array}{lll}0.13 \quad 4 & 0.02\end{array}$

$\begin{array}{lll}0.16 & 2 & 0.01\end{array}$

$\begin{array}{lll}0.14 & 3 & 0.06\end{array}$

$\begin{array}{lll}0.02 & 1 & 0.00\end{array}$

$\begin{array}{lll}0.06 & 2 & 0.01\end{array}$

$\begin{array}{lll}0.10 & 5 & 0.00\end{array}$

$\begin{array}{lll}0.11 \quad 5 & 0.06\end{array}$ $\begin{array}{lll}0.06 & 2 & 0.00\end{array}$

$\begin{array}{lll}0.11 & 2 & 0.00\end{array}$

$\begin{array}{lll}0.13 \quad 4 & 0.0\end{array}$

$0.11 \quad 4 \quad 0.01$

$0.14 \quad 4 \quad 0.00$

$\begin{array}{lll}0.16 \quad 3 & 0.00\end{array}$

$\begin{array}{lll}0.12 & 3 & 0.00\end{array}$

$\begin{array}{lll}0.24 & 3 & 0.14\end{array}$

$\begin{array}{lll}0.09 & 5 & 0.00\end{array}$

$\begin{array}{lll}0.09 & 3 & 0.00\end{array}$

$\begin{array}{lll}0.16 & 1 & 0.00\end{array}$

$\begin{array}{lll}0.12 & 2 & 0.00\end{array}$

$\begin{array}{lll}0.14 & 4 & 0.00\end{array}$

$\begin{array}{lll}0.05 & 6 & 0.00\end{array}$

$\begin{array}{lll}0.12 & 3 & 0.00\end{array}$

$\begin{array}{lll}0.15 & 3 & 0.02\end{array}$

$0.12 \quad 3 \quad 0.00$

$\begin{array}{lll}0.24 & 1 & 0.39\end{array}$

$\begin{array}{lll}0.15 & 3 & 0.00\end{array}$

$\begin{array}{lll}0.08 & 3 & 0.00\end{array}$

$\begin{array}{lll}0.08 & 7 & 0.01\end{array}$

$\begin{array}{lll}0.17 \quad 3 & 0.00\end{array}$

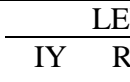

$\begin{array}{lll}0.16 & 2 & 0.00\end{array}$

$\begin{array}{lll}0.05 & 3 & 0.05\end{array}$

$\begin{array}{lll}0.36 & 3 & 0.00\end{array}$

$\begin{array}{lll}0.37 & 3 & 0.01\end{array}$

$\begin{array}{lll}0.05 & 6 & 0.04\end{array}$

$\begin{array}{lll}0.40 & 2 & 0.02\end{array}$

$\begin{array}{lll}0.34 & 1 & 0.00\end{array}$

$\begin{array}{lll}0.31 & 2 & 0.05\end{array}$

$\begin{array}{lll}0.22 & 3 & 0.00\end{array}$

$\begin{array}{lll}0.21 \quad 3 & 0.02\end{array}$

$\begin{array}{lll}0.16 \quad 2 & 0.00\end{array}$

$\begin{array}{lll}0.19 & 1 & 0.00\end{array}$

$\begin{array}{lll}0.22 & 2 & 0.01\end{array}$

$\begin{array}{lll}0.02 \quad 7 & 0.00\end{array}$

$\begin{array}{lll}0.23 & 1 & 0.00\end{array}$

$\begin{array}{lll}0.07 \quad 3 & 0.00\end{array}$

$\begin{array}{lll}0.15 & 1 & 0.07\end{array}$

$\begin{array}{lll}0.22 & 3 & 0.12\end{array}$

$\begin{array}{lll}0.16 \quad 2 & 0.00\end{array}$

$\begin{array}{lll}0.10 & 2 & 0.00\end{array}$

$\begin{array}{lll}0.17 & 3 & 0.01\end{array}$

$\begin{array}{lll}0.08 \quad 6 & 0.0\end{array}$

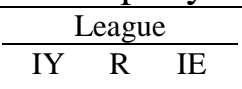

IY R

$\begin{array}{lll}0.05 & 4 & 0.00\end{array}$

$\begin{array}{lll}0.19 & 1 & 0.03\end{array}$

$\begin{array}{lll}0.24 & 1 & 0.00\end{array}$

$0.17 \quad 2 \quad 0.00$

$0.31 \quad 1 \quad 0.02$

$\begin{array}{lll}0.27 & 1 & 0.00\end{array}$

$\begin{array}{lll}0.17 & 2 & 0.05\end{array}$

$\begin{array}{lll}0.42 \quad 1 & 0.01\end{array}$

$\begin{array}{lll}0.48 & 1 & 0.04\end{array}$

$\begin{array}{lll}0.57 & 1 & 0.27\end{array}$

$\begin{array}{lll}0.08 \quad 2 & 0.00\end{array}$

$\begin{array}{lll}0.14 & 2 & 0.00\end{array}$

$\begin{array}{lll}0.14 & 2 & 0.00\end{array}$

$\begin{array}{lll}0.13 & 1 & 0.00\end{array}$

$\begin{array}{lll}0.07 & 5 & 0.02\end{array}$

$\begin{array}{lll}0.36 & 1 & 0.03\end{array}$

$\begin{array}{lll}0.40 & 1 & 0.05\end{array}$

$\begin{array}{lll}0.28 & 1 & 0.15\end{array}$

$0.08 \quad 4 \quad 0.00$

$\begin{array}{lll}0.23 & 2 & 0.09\end{array}$

$\begin{array}{lll}0.10 & 6 & 0.01\end{array}$

$0.07 \quad 4 \quad 0.00$

$\begin{array}{lll}0.16 \quad 4 & 0.05\end{array}$

$0.14 \quad 4 \quad 0.01$

$\begin{array}{lll}0.09 & 2 & 0.00\end{array}$

$\begin{array}{lll}0.08 & 5 & 0.00\end{array}$

$\begin{array}{lll}0.19 & 1 & 0.00\end{array}$

$0.08 \quad 4 \quad 0.00$

$\begin{array}{lll}0.17 \quad 4 & 0.00\end{array}$

$\begin{array}{lll}0.15 \quad 4 & 0.00\end{array}$

$0.13 \quad 4 \quad 0.00$

$\begin{array}{lll}0.08 & 3 & 0.00\end{array}$

$\begin{array}{lll}0.13 \quad 2 & 0.00\end{array}$

$\begin{array}{lll}0.05 & 1 & 0.00\end{array}$

$\begin{array}{lll}0.08 & 3 & 0.00\end{array}$

$\begin{array}{lll}0.10 & 4 & 0.00\end{array}$

$0.23 \quad 2 \quad 0.06$

$\begin{array}{lll}0.13 & 2 & 0.00\end{array}$

$\begin{array}{lll}0.20 & 4 & 0.00\end{array}$

$\begin{array}{lll}0.21 & 1 & 0.00\end{array}$

$\begin{array}{lll}0.38 & 1 & 0.00\end{array}$

$\begin{array}{lll}0.22 & 1 & 0.03\end{array}$

$\begin{array}{lll}0.19 & 2 & 0.03\end{array}$

\section{PD}

\begin{tabular}{lllll}
\hline $\mathrm{PD}$ & & & \multicolumn{2}{c}{+ EUR } \\
\cline { 5 - 5 } \cline { 4 - 5 } & & $\mathrm{IE}$ & & $\mathrm{R} \quad \mathrm{IE}$
\end{tabular}

$\begin{array}{lll}0.15 & 3 & 0.00\end{array}$

$\begin{array}{lll}0.21 & 1 & 0.00\end{array}$

$\begin{array}{lll}0.56 & 1 & 0.00\end{array}$

$\begin{array}{lll}0.46 \quad 1 & 0.05\end{array}$

$\begin{array}{lll}0.11 \quad 5 & 0.00\end{array}$

$\begin{array}{lll}0.43 & 1 & 0.00\end{array}$

$\begin{array}{lll}0.30 \quad 2 & 0.00\end{array}$

$\begin{array}{lll}0.26 & 3 & 0.01\end{array}$

$\begin{array}{lll}0.32 & 1 & 0.01\end{array}$

$\begin{array}{lll}0.34 & 1 & 0.02\end{array}$

$0.08 \quad 4 \quad 0.00$

$\begin{array}{lll}0.06 & 4 & 0.01\end{array}$

$\begin{array}{lll}0.43 & 1 & 0.10\end{array}$

$\begin{array}{lll}0.06 & 5 & 0.00\end{array}$

$\begin{array}{lll}0.10 & 2 & 0.00\end{array}$

$\begin{array}{lll}0.21 & 1 & 0.00\end{array}$

$\begin{array}{lll}0.23 & 1 & 0.00\end{array}$

$\begin{array}{lll}0.33 & 1 & 0.12\end{array}$

$\begin{array}{lll}0.14 \quad 4 & 0.04\end{array}$

$\begin{array}{lll}0.10 & 1 & 0.02\end{array}$

$\begin{array}{lll}0.21 & 2 & 0.06\end{array}$

$\begin{array}{lll}0.19 & 1 & 0.07\end{array}$ $\begin{array}{lll}0.03 & 3 & 0.00 \\ 0.08 & 6 & 0.00\end{array}$

$0.04 \quad 7 \quad 0.01$

$\begin{array}{lll}0.03 & 3 & 0.00\end{array}$

$\begin{array}{lll}0.04 \quad 4 & 0.03\end{array}$

$\begin{array}{lll}0.47 \quad 2 & 0.02\end{array}$

$\begin{array}{lll}0.43 \quad 2 & 0.39\end{array}$

$\begin{array}{lll}0.04 & 1 & 0.02\end{array}$

$\begin{array}{lll}0.30 & 3 & 0.00\end{array}$

$0.29 \quad 3 \quad 0.00$

$\begin{array}{lll}0.33 & 1 & 0.16\end{array}$

$0.31 \quad 2 \quad 0.03$

$\begin{array}{lll}0.32 & 2 & 0.02\end{array}$

$0.47 \quad 1 \quad 0.04$

$0.05 \quad 3 \quad 0.00$

$\begin{array}{lll}0.16 & 3 & 0.01\end{array}$

$0.07 \quad 4 \quad 0.00$

$\begin{array}{lll}0.08 \quad 3 & 0.01\end{array}$

$\begin{array}{lll}0.18 & 2 & 0.01\end{array}$

$\begin{array}{lll}0.06 & 3 & 0.00\end{array}$

$\begin{array}{lll}0.22 & 2 & 0.00\end{array}$

$0.11 \quad 5 \quad 0.00$ 
Table A3. Top-5 Issue Yield goals for minor Italian parties (valence issues in italics).

\begin{tabular}{|c|c|c|c|}
\hline Party & Goal & IY & $\begin{array}{l}\text { IY Cross- } \\
\text { party } \\
\text { ranking }\end{array}$ \\
\hline \multirow{5}{*}{$\overline{\mathrm{P}}$} & Limit the number of refugees & 0.34 & 2 \\
\hline & Decriminalise excess of self-defence & 0.31 & 2 \\
\hline & Restrict access to welfare benefits for immigrants & 0.29 & 2 \\
\hline & Keep current legislation on citizenship for immigrants' sons & 0.23 & 2 \\
\hline & Making citizens safer from crime & 0.20 & 2 \\
\hline \multirow{5}{*}{ 김 } & Make citizenship for regular immigrants' sons easier & 0.40 & 2 \\
\hline & Stay in the EU & 0.37 & 3 \\
\hline & Stay in the Euro & 0.36 & 3 \\
\hline & Keep current levels of access to welfare benefits for immigrants & 0.34 & 1 \\
\hline & Continue to accept refugees like now & 0.31 & 2 \\
\hline \multirow{5}{*}{$\underset{\substack{5 \\
\text { 㭊 }}}{ }$} & Stay in the Euro & 0.47 & 2 \\
\hline & Legalise soft drugs & 0.47 & 1 \\
\hline & Stay in the EU & 0.43 & 2 \\
\hline & Continue to accept refugees like now & 0.33 & 1 \\
\hline & Keep same-sex unions & 0.32 & 2 \\
\hline
\end{tabular}


Table A4. Top-5 goals by Issue Emphasis on Twitter for minor Italian parties (valence issues in italics).

\begin{tabular}{|c|c|c|c|}
\hline Party & Goal & IE & $\begin{array}{c}\text { IY cross- } \\
\text { party } \\
\text { ranking }\end{array}$ \\
\hline \multirow{5}{*}{$\overrightarrow{\mathrm{\theta}}$} & Limit the number of refugees & 0.22 & 2 \\
\hline & Making citizens safer from crime & 0.22 & 2 \\
\hline & Decriminalise excess of self-defence & 0.09 & 2 \\
\hline & Fight pollution and disruption of territory & 0.08 & 7 \\
\hline & Increase economic bonuses to families with children & 0.06 & 5 \\
\hline \multirow{5}{*}{$\stackrel{D}{\text { 团 }}$} & Fight pollution and disruption of territory & 0.21 & 5 \\
\hline & Ensure the good functioning of healthcare system & 0.14 & 6 \\
\hline & Keep tax progressivity on income & 0.12 & 3 \\
\hline & Improve Italian education & 0.09 & 6 \\
\hline & Scrap the cost of university tuition fees & 0.06 & 1 \\
\hline \multirow{5}{*}{ 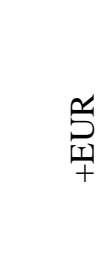 } & Stay in the EU & 0.39 & 2 \\
\hline & Continue to accept refugees like now & 0.16 & 1 \\
\hline & Support economic growth & 0.10 & 7 \\
\hline & Make Italy count more in Europe & 0.05 & 5 \\
\hline & Renew Italian politics & 0.05 & 7 \\
\hline
\end{tabular}

Note: goals that were among the top-5 according to IY are in bold. 
Table A5. Issue strategies for various Italian parties: Effects of Issue Yield and Systemic Salience on Issue Emphasis.

\begin{tabular}{|c|c|c|c|c|}
\hline \multirow[b]{2}{*}{ IY } & \multicolumn{2}{|c|}{ Model 1} & \multicolumn{2}{|c|}{ Model 2} \\
\hline & $0.30^{* * * *}$ & $(0.07)$ & $0.41^{* * *}$ & $(0.01)$ \\
\hline SS & $0.22^{* * *}$ & $(0.03)$ & $0.22^{* * *}$ & $(0.01)$ \\
\hline \multicolumn{5}{|c|}{ +EUR (reference category) } \\
\hline LEU & & & $0.14^{* * * *}$ & $(0.00)$ \\
\hline FDI & & & $-0.05^{* * *}$ & $(0.01)$ \\
\hline FI & & & $-0.03^{* * *}$ & $(0.01)$ \\
\hline League & & & $0.07^{* * * *}$ & $(0.00)$ \\
\hline $\mathrm{PD}$ & & & 0.00 & $(0.01)$ \\
\hline M5S & & & $-0.20^{* * *}$ & $(0.05)$ \\
\hline \multicolumn{5}{|c|}{ +EUR (reference category) x IY } \\
\hline LEU x IY & & & $-0.42^{* * *}$ & $(0.01)$ \\
\hline FDI x IY & & & $0.28^{* * *}$ & $(0.02)$ \\
\hline FI x IY & & & $0.92^{* * * *}$ & $(0.02)$ \\
\hline League x IY & & & $-0.09^{* * *}$ & $(0.01)$ \\
\hline PD x IY & & & $-0.24^{* * *}$ & $(0.00)$ \\
\hline M5S x IY & & & $-0.18^{* * *}$ & $(0.01)$ \\
\hline \multicolumn{5}{|c|}{ +EUR (reference category) $\times \mathrm{SS}$} \\
\hline LEU x SS & & & $-0.10^{* * * *}$ & $(0.00)$ \\
\hline FDI x SS & & & $0.03^{* *}$ & $(0.01)$ \\
\hline FI x SS & & & $-0.15^{* * *}$ & $(0.01)$ \\
\hline League x SS & & & $-0.07^{* * *}$ & $(0.00)$ \\
\hline $\mathrm{PD} \times \mathrm{SS}$ & & & $0.03^{*}$ & $(0.01)$ \\
\hline M5S x SS & & & $0.24^{* * * *}$ & $(0.05)$ \\
\hline Constant & $-0.22^{* * *}$ & $(0.04)$ & $-0.23^{* * *}$ & $(0.01)$ \\
\hline Sigma Constant & $0.08^{* * * *}$ & $(0.01)$ & $0.07^{* * *}$ & $(0.01)$ \\
\hline Observations & 2 & & & \\
\hline$A I C$ & $-14 c$ & & & \\
\hline$B I C$ & -13 & & & \\
\hline VarExp & 0.2 & & & \\
\hline
\end{tabular}




\section{List of figures}

Figure 1. Issue preferences and salience for major Italian party constituencies.

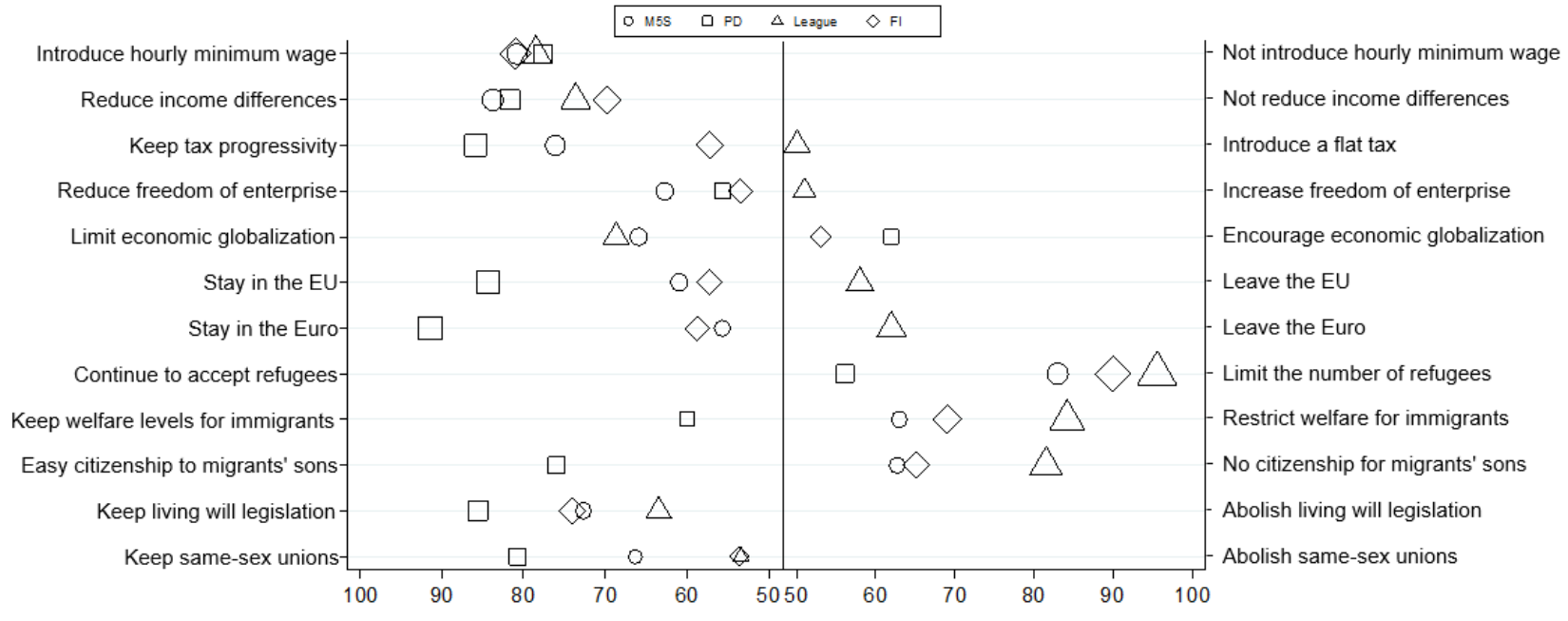

Note: On each positional issue we placed party constituencies according to the percentage of respondents in that constituency who support the favoured among the two rival goals. The size of markers is proportional to the salience assigned to that goal by respondents in that constituency who support that goal. 
Figure A1. Results of legislative elections in Italy (Chamber), 2008-2018.

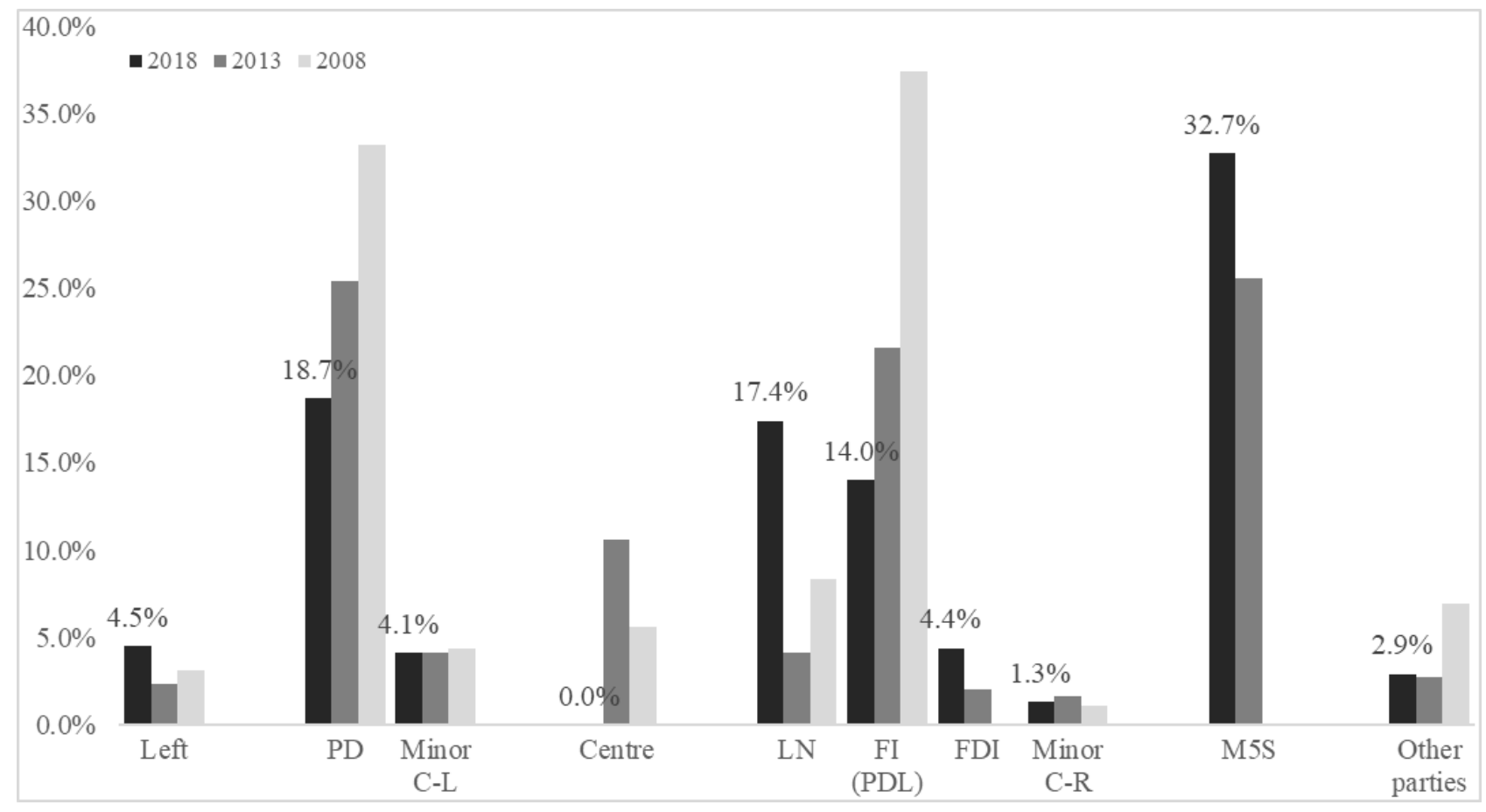


Figure A2. Marginal effects of Issue Yield and Systemic Salience on Issue Emphasis for Italian parties.

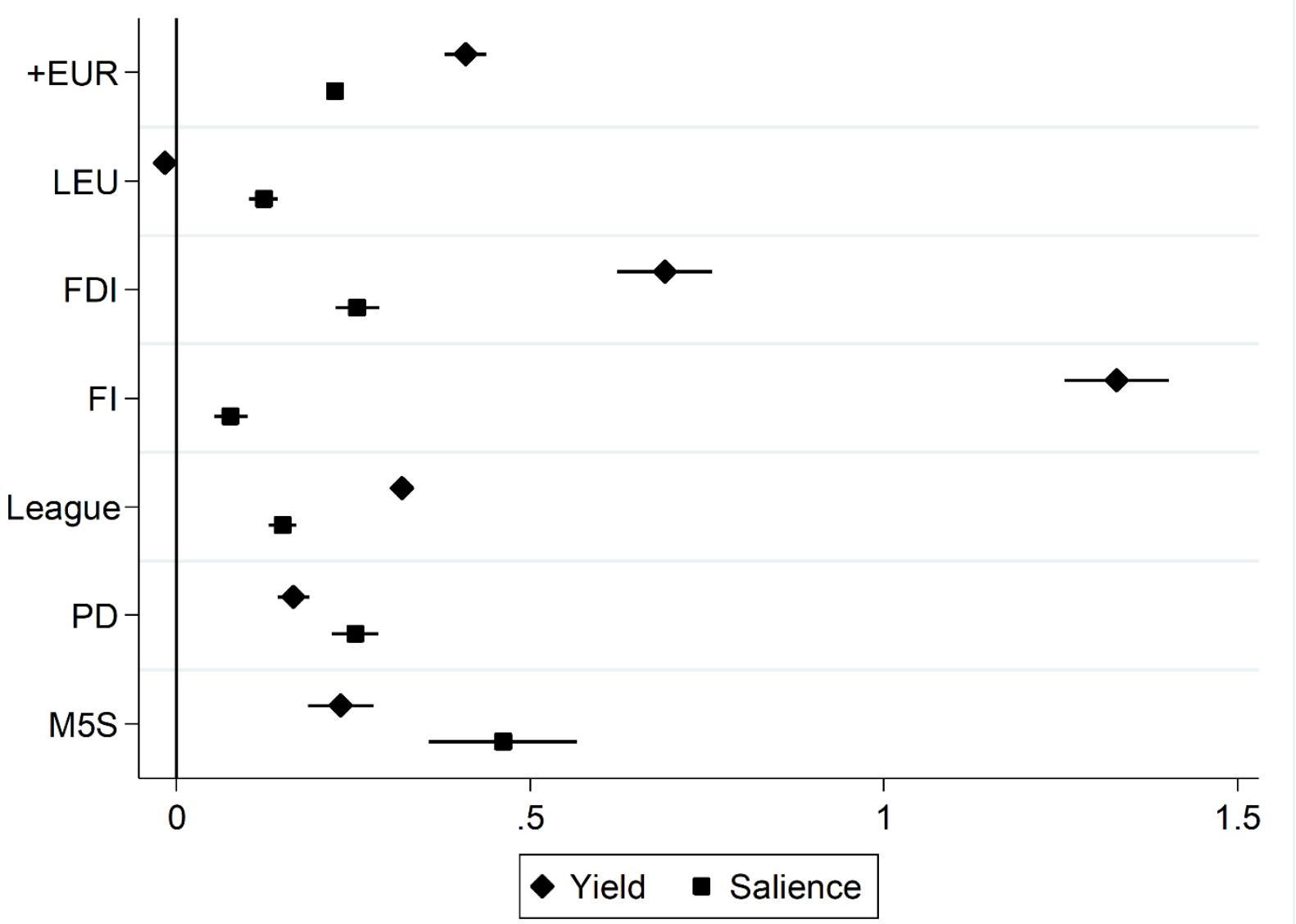

Note: The chart represents graphically the Tobit Model 2 reported in Table A5 in Appendix B. Diamonds represent the conditional effect of issue yield on Twitter emphasis for different parties. Squares represent the conditional effect of systemic salience on Twitter emphasis for different parties. Only the values for the subpopulation of issues with at least one tweet $E\left(E m p h_{i j} \mid E m p h_{i j}>0\right)$ are reported. Horizontal bars represent $95 \%$ confidence intervals. 